\title{
The CARES Act: Are the Tax and Financial Relief Provisions Sufficient in a Time of Economic Crisis?
}

\author{
Constance J. Crawford ${ }^{1}$, Corinne L. Crawford ${ }^{2}$, Glenn C. Vallach ${ }^{1}$ \\ ${ }^{1}$ Anisfield School of Business, Ramapo College of New Jersey, Mahwah, NJ, USA \\ ${ }^{2}$ Borough of Manhattan Community College, City University of New York, New York, NY, USA \\ Email: ccrawfor@ramapo.edu
}

How to cite this paper: Crawford, C. J., Crawford, C. L., \& Vallach, G. C. (2020). The CARES Act: Are the Tax and Financial Relief Provisions Sufficient in a Time of Economic Crisis? Modern Economy, 11, 1522-1527.

https://doi.org/10.4236/me.2020.119108

Received: July 25, 2020

Accepted: September 18, 2020

Published: September 21, 2020

Copyright $\odot 2020$ by author(s) and Scientific Research Publishing Inc. This work is licensed under the Creative Commons Attribution International License (CC BY 4.0).

http://creativecommons.org/licenses/by/4.0/

\begin{abstract}
The impact of the COVID-19 Pandemic has been staggering for the entire US economic system. Entire industries have been thwarted from operating on any sustainable level. In response, Wall Street reacted with a resounding CRASH... and so... the need for federal intervention became a stark reality for the US economic system's survival. As major retailers collapse into bankruptcy, the need for continued federal financial support is tantamount to survival for a wide array of fledgling companies. Will the CARES legislation be sufficient to prevent a United States' economic freefall?
\end{abstract}

\section{Keywords}

CARES Act, Bankruptcy, Pandemic

\section{Introduction}

The problem of how-to arrest the flow of corporate failures and thwart an epidemic of bankruptcy filings is currently the primary focus of the US economic system (Parrott et al., 2020). Entire Industries, including: Retail, Airline, Cruise Line and Hotels, were preventing from operating on any sustainable level as a result of a federal mandate (Snell, 2020). The inability of major segments of the US economy to function on any sustainable level, required a financial bailout. In essence, the federal government became the independent $3^{\text {rd }}$ party financial funding source disguised as legislation (McConnell, 2020). The question that loomed large on the minds of the investment community was: "What can Congress due to prevent a crash that would exceed even the 1929 debacle?" The answer was presented in the form of a legislative pronouncement known as the CARES Act 
(Kelly, 2020).

\section{Economic Impact Caused by the Pandemic}

The COVID-19 Pandemic began in China most probably in the late fall of 2019 and quickly spread throughout the world (Parrott et al., 2020). By March 2020, the Coronavirus' devasting impact resulted in the shut-down of the entire United States economic system. Schools closed, businesses shuttered, and emergency rooms were overwhelmed with the rising tide of infected COVID-19 patients. Governors and Mayors across the US mandated "stay at home rules". Unfortunately, not only did the virus create a health emergency but it also caused an unforeseen economic crisis (C.B.O., 2020).

The new "norm" included remote learning for all schools, face masks to be donned in public and the requirement for social distancing of a minimum of 6 feet (US Dept HHS, 2020). The result of such stringent restrictions created an atmosphere of uncertainty and a fear that the virus would negatively alter people's lives forever (Bunn et al., 2020). Neither of those two outcomes provides a level of confidence to sustain a viable US economic atmosphere (Schnitter et al., 2020). The inability to shop for food and medicines became a previously unknown challenge, impacting the most vulnerable in our society. Take-out became the only option for restaurant fare and travel was restricted both internationally and domestically.

Unfortunately, as the US population struggled to cope with the health effects of a Pandemic lifestyle, certain problematic and unsettling economic trends began to emerge (Bunn et al., 2020). The unprecedented rise in major retail bankruptcy filings created a crisis for commercial realtors as malls lost their anchor stores and massive layoffs of retail workers', created an avalanche of unemployment claims (C.B.O., 2020). The crisis impacted the upscale shopping mecca of Hudson Yards as a result of the bankruptcy of their anchor store Neiman-Marcus along with the strip malls of middle-income shoppers with the demise of Sears and JC Penny.

The bankruptcy filings essentially negated the lease contracts entered into by the now debtor-in-possession retail entities and thwarted landlords from eviction options (Parrott et al., 2020). The entire landscape of large metropolitan cities was altered by the shuttered storefronts and lack of any commuters or the always desirable summer tourists. A once enviable geographic locale, like New York City, became an overnight ghost town.

The complete shut-down of entire industries, due to the pandemic, created an economic freefall cascading into massive losses as revenue growth collapsed (Parrott et al., 2020). So many industries, some expected others not, fell victim to the COVID-19 economic fallout. The oil \& gas industry, for example, was an unanticipated victim resulting from both a lack of demand and an international power struggle regarding production. Cruise ships were unable to find a port resulting in a multitude of employees trapped on board for months as the Coronavirus 
continued on its' relentless journey. Airlines were hobbled as they could only fly to limited destinations coupled with an extreme lack of demand. With no travelers, the demand for both hotels and Airbnb rentals fell, along with the stock market (Bunn et al., 2020).

The Stock Market reaction was overwhelmingly negative as a once heralded low unemployment rate began to increase in a manner reminiscent of the 1929 depression. Clearly the world, along with the United States, was in a Pandemic crisis mode and the governments throughout the world, became the only lifeboat available in the chaotic storm known as the Covid-19 Pandemic (Parrott et al., 2020).

\section{The Response: The CARES Act: The Answer to Corporate America's Crisis?}

On March 27, 2020, President Trump signed into law the Coronavirus Aid, Relief, and Economic Security Act (H.R. 748) (the "CARES Act") (Kelly, 2020). On March 18, 2020, President Trump signed into law the Families First Coronavirus Response Act (H.R. 6201) (the "FFCRA"), which includes the Emergency Paid Sick Leave Act and the Emergency Family and Medical Leave Expansion Act ("FMLA Expansion Act") (Bunn et al., 2020).

The legislation was intended to alleviate the strain of unemployment for the US worker and provided much needed financial support for fledgling industries (C.B.O., 2020). The CARES Act included the following tax relief provisions aimed at assisting the crippling economic crisis (McConnell, 2020):

\section{CARES Act: Tax Relief Corporate Provisions}

\subsection{Reinstate the Net Operating Losses and Other Deductions for Businesses}

Net operating losses ("NOLs") provide taxpayers to ability to reduce certain business income on their tax returns. However, the Internal Revenue Code (the "IRC") had disallowed NOLs to be carried back to prior tax years and limited the use of NOLs to $80 \%$ of taxable income for future taxable years as per the 2017 Tax Cuts and Jobs Act (TCJA) (McConnell, 2020). Due to the Pandemic crisis, the CARES Act amends Section 172(b) (1) of the IRC to once again allow taxpayers to carry back NOLs from 2018, 2019 and 2020 for up to five years (McConnell, 2020).

Additionally, the 2017 TCJA limited the amount of net business loss that a non-corporation taxpayer could reduce their income by to $\$ 250,000$ for individuals and \$500,000 for joint filers effective January 1, 2018 (McConnell, 2020). The CARES Act postpones the effective date of the limitation to January 1, 2021 and provides for taxpayers to file amended returns to recoup a prior tax consequence (McConnell, 2020).

The CARES Act includes provisions that increase the deduction for business interest from 30\% to 50\% of adjusted taxable income for 2019 and 2020 (McCon- 
nell, 2020).

\subsection{Delayed Employer Payroll and Self-Employment Tax Payments}

The due date of the employers' portion of the employees' payroll tax of $6.2 \%$ for FICA or Social Security and $50 \%$ of the $12.4 \%$ self-employment tax was postponed by the CARES Act as well (El-Sibaie et al., 2020). The extension for 50\% of such taxes will be December 31, 2021 and the due date for the remaining 50\% of such taxes will be December 31, 2022 (El-Sibaie et al., 2020).

\subsection{Employee Retention \& FFCRA Credit}

The CARES Act includes incentives for employers to retain employees during the Pandemic (SSA, 2020). The Act provides for employers to receive an employee retention credit for qualified wages limited to $\$ 10,000$ per employee (McConnell, 2020). The credit provides for $50 \%$ of such employer's qualified wages from March 13, 2020 to December 31, 2020 for each employee (McConnell, 2020). In addition, the CARES Act provides for similar tax credits to offset mandatory FFCRA paid leave expenses (El-Sibaie et al., 2020).

\subsection{Depreciation of Qualified Improvement Property}

The CARES Act provides for the immediate write-off of qualified improvement property in an attempt to accelerate the cost recovery provisions of the IRC and provide an additional incentive to purchase new property (LaBrecque, 2020).

The 2017 Tax Cut and Jobs Act included a similar provision, but the language was challenged and therefore ineffective (Bunn et al., 2020). The CARES Act revises that problematic verbiage. Once again, the CARES Act provides for amended return filing provisions to recapture prior tax payments (McConnell, 2020).

\subsection{Charitable Contributions}

The CARES Act amends the $10 \%$ limitation for corporate charitable contributions to $25 \%$ of their taxable income (McConnell, 2020).

\section{Critique of the CARES Act: Will the CARES Act Financial and Tax Provisions Remedy the Financial Crisis Caused by the Pandemic?}

Clearly many of the provisions and tax remedies provided by the CARES Act will alleviate some of the financial crisis caused by the Pandemic. Several of the CARES Act provisions provide opportunities for the recapture of prior taxes in an attempt to alleviate cash flow issues for cash starved businesses (Bunn et al., 2020). Most notably, the reintroduction of the Net Operating Loss (NOL) carryback provision will allow for the recapture of prior period taxes, which should alleviate cash liquidity issues for some struggling entities (LaBrecque, 2020). Additionally, the rewording of the depreciation tax guidelines will also provide for 
both cash refunds via amended returns for 2018 and 2019 along with a potential incentive for future acquisitions of property (Bunn et al., 2020). The deferment of employers' tax payments for payroll along with the employee retention credit should provide incentives for employers to resist the urge to lay-off employees in an attempt to salvage their businesses (US Dept Treas, 2020).

The $\$ 600$ additional unemployment payment provides needed financial security for the overwhelming number of unemployed workers (Parrott et al., 2020). The much-needed cash flow provided a financial safety net for the recently furloughed and unemployed workers. The restrictions placed on landlords, pertaining to unpaid rental eviction limitations, provides a level of security for tenants, both residential and commercial, who were the victims of a relentless enemy. The CARES Act attempted to assure all of the victims of the COVID-19 Pandemic, that the federal government, would provide a financial life preserver (Kelly, 2020). One that was clearly lacking during the early days of the 1929 depression.

\section{Conclusion}

Whether the provisions of the CARES Act, which includes a multitude of tax reduction provisions and cash flow assistance remains questionable, at best. Congress is currently engaged in a debate over whether to extend the additional $\$ 600$ weekly unemployment provisions, which some believe provides a disincentive to return to work, whether to discontinue the employee/er tax withholdings for Social Security, which may deplete the already burdened Social security coffers, and whether to provide financial bailout provisions for states and municipalities, which perhaps may be a consequence of prior poor governmental decision-making, continues to be discussed (LaBrecque, 2020). The United States economy continues to struggle within a Pandemic atmosphere of fear, as evidenced by the plethora of current and pending bankruptcy filings. Congress attempted to provide tax relief via the CARES Act legislation, but as far as the remedy it ultimately provides to a precarious entity on the verge of bankruptcy or an unemployed worker, remains, an unanswerable question, at best.

\section{Conflicts of Interest}

The authors declare no conflicts of interest regarding the publication of this paper.

\section{References}

Bunn, D., LaJoie, T. et al. (2020). Congress Approves Economic Relief Plan for Individuals and Businesses. Tax Foundation.

https://taxfoundation.org/cares-act-senate-coronavirus-bill-economic-relief-plan/

C.B.O. (2020). H.R.748 CARES Act Public Law 116-136. Congressional Budget Office. https://www.cbo.gov/publication/56334

El-Sibaie, A., York, S. et al. (2020). FAQ on Federal Coronavirus Relief Law (CARES Act). Tax Foundation. https://taxfoundation.org/cares-act/FAQ 
Kelly, A. (2020) Final Final CARES Act. NPR.

https://www.documentcloud.org/documents/6819239-FINAL-FINAL-CARES-ACT.html

LaBrecque, L. (2020). The CARES Act Has Passed, Here Are the Highlights. Forbes Magazine.

https://www.forbes.com/sites/leonlabrecque/2020/03/29/the-cares-act-has-paseed-here -are-the-highlights/\#3d5d8aa368cd

McConnell, M. (2020). Coronavirus Aid, Relief and Economic Securities Act. U.S. Congress Bill S.3548. https://www.congress.gov/bill/116th-congress/senate-bill/3548/

Parrott, S., Stone, C. et al. (2020). CARES Act Includes Essential Measures to Respond to Public Health, Economic Crises, but More Will Be Needed. Center on Budget \& Policy Priorities.

https://www.cbpp.org/research/economy/cares-act-includes-essential-measures-to-resp ond-to-public-health-economic-crises

Schnitter, D., Stewart, D. et al. (2020) Public Policy Briefing-The CARES Act. The National Law Review.

https://www.natlawreview.com/article/public-policy-briefing-july-23-2020

Snell, K. (2020). What's inside the Senate's \$2 Trillion Coronavirus Aid Package. NPR Political Newsletter.

https://www.npr.org/2020/03/28/821457551/whats-inside-the-senate-s-2-trillion-coron avirus-aid-package

SSA. (2020). Coronavirus (COVID-19) Update. The Social Security Administration. https://www.ssa.gov/coronavirus/eip-cares-act/

US Dept HHS. (2020). CARES Act Provider Relief Fund. U.S. Dept. of Health \& Human Resources. https://www.hhs.gov/coronavirus/cares-act-provider-relief-fund/index.html

US Dept Treas. (2020). The CARES Act Works for All Americans. U.S. Department of the Treasury. https://home.treasury.gov/policy-issues/cares 